\title{
Oyunlaştırma Yöntemi Doğrultusunda Geliştirilen "Gitarist" Adlı Mobil Uygulamaya Yönelik Öğrenci Görüşlerinin Değerlendirilmesi
}

\author{
An Evaluation on Students' Opinion About Mobile Application Titled \\ "Guitarist” Developed Through Gamification Method
}

\section{Tuncay Aras}

Arş. Gör., Atatürk Üniversitesi Güzel Sanatlar Fakültesi Müzik Bilimleri Bölümü

email: tuncay.aras@atauni.edu.tr (DORCID ID: https://orcid.org/0000-0002-9413-3351

* Bu çalışma EGT-CDRP-101018-0522 numaralı Marmara Üniversitesi Bilimsel Araştırma Projesi ile desteklenen "Çalgı (Gitar) Eğitiminde Oyunlaştırma Yöntemine Yönelik Eğitsel Yazılım Geliştirme Çalışması” isimli doktora tezinden üretilmiştir.

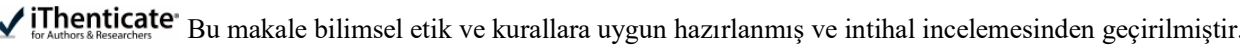

Atıf (APA 6)/To cite this article

Aras, T. (2020). Oyunlaştırma yöntemi doğrultusunda geliştirilen "Gitarist" adlı mobil uygulamaya yönelik öğrenci görüşlerinin değerlendirilmesi. Atatürk Üniversitesi Güzel Sanatlar Enstitüsü Dergisi, 26(Müzik Özel Sayıs1), 366-373. doi: https://doi.org/10.35247/ataunigsed.684400

Makale Gönderim Tarihi/Received: 04/12/2019

Makale Kabul Tarihi/Accepted: 19/02/2020

Makale Yayın Tarihi/Published: 25/03/2020

Research Article / Araștırma Makalesi

\section{Öz}

Teknolojik gelişmeler, eğitim alanında farklı yöntemlere olan ihtiyaçları beraberinde getirmektedir. Günümüz neslini derse odaklayabilmek, motive edebilmek, dersi eğlenceli hale getirebilmek gibi durumlar bağlamında oyunlaştırma yönteminin önemli olduğu düşünülmektedir. Günümüzde oyunlaștırma yöntemine yönelik farklı alanlarda yapılan çalışmalar ile karşılaşı1sa da müzik eğitimi alanında oyunlaştırmayı temel alan çalısmaların olmayıșı dikkat çekicidir. Bu noktadan hareketle müzik eğitiminin alt boyutu olan çalgı eğitimi içerisinde oyunlaștırma yöntemine yönelik yapılan araștırmaların eksikliği çalışmanın problem durumunu oluşturmaktadır.

Araştırmada, çalgı (gitar) eğitimi dersi için oyunlaştırma yöntemi doğrultusunda geliștirilen Gitarist adlı mobil uygulamaya yönelik öğrenci görüşlerinin değerlendirilmesi amaçlanmıştır.

Araştırmada, yarı yapılandırılmış görüşme tekniğinden yararlanılmıs ve öğrenci görüșlerinin değerlendirilmesi amacıyla 8 sorudan oluşan yarı yapılandırılmış görüş̧me formu veri toplama aracı olarak kullanılmıștır. Hazırlanan görüsme formu, Kars Gülahmet Aytemiz Güzel Sanatlar Lisesi müzik bölümü 9. sınıf 6 gitar öğrencisi üzerinde uygulanmış ve toplanan veriler içerik analizi yöntemi kullanılarak incelenmiștir.

Araştırmada, öğrenciler ile yapılan bire bir görüşmeler sonucunda elde edilen bulgular ortaya konularak mevcut durum tespit edilmiş ve bu tespit sonucunda çözüm önerilerine yer verilmisțir.

Anahtar Kelime: Oyunlaştırma, Çalg1 Eğitimi, Müzik Eğitimi, Yazılım

\begin{abstract}
Technological developments have required the need for different methods in the field of education. It is thought that gamification method is important within the context of focusing present generation on the course, motivating them, and making the course fun. Although studies in different fields on gamification method are encountered today, the absence of studies based on gamification in the field of music education is noticeable. The lack of research on gamification method in instrument training, which is the sub-field of music education, forms the problem of the study.

The aim of this study is to evaluate the students' opinion about the mobile application titled Guitarist, which has been developed through gamification method for instrument training.

In the research, semi-structured interview technique was used and semi-structured interview form consisting of 8 questions was used as a data collection tool to evaluate student views. The interview form was applied on six 9th grade students of Kars Gulahmet Aytemiz Fine Arts High School music department and the collected data were analyzed using the content analysis method.

In the research, the findings obtained as a result of one-to-one interviews with students were revealed, and the current situation was determined and suggestions were included as a result of this determination.
\end{abstract}

Key Words: Gamification, Instrument Education, Music Education, Software

\section{Giriş}

Tarihte her zaman yer edinmiş bir kavram olarak oyununun, insanoğlu üzerindeki güçlü etkisinin temelinde, gerçek yaşamın sınırlarını zorlayıcı özelliklerinin rol aldığını söylemek mümkündür. "Oyunun varlığı hiçbir uygarlık basamağına, evreni kavrayışın hiçbir biçimine bağlı değildir. Her düşünen varlık, dili oyunu tanımlayacak genel terime sahip olmasa bile, bu oyun ve oynama gerçeğini bizatihi bağımsız bir şey olarak tasarlayabilir. Oyunun varlığı inkar edilemez niteliktedir" (Huizinga, 2006, s.19). Geçmişten başlayıp insanoğlunun yaşamına bir şekilde etki eden ve eğlence kavramını en iyi yansıtan oyun olgusu, günümüzde çağın gerekleri doğrultusunda insan yaşamında farklı şekillerde yer almaktadır. "Geçmişte, özellikle 1970'lerde, video oyunları terimi "oyun 
salonlarında oynanan oyunlar" anlamına gelirken, bugünün bağlamında bu terim, bilgisayarları, oyun konsollarını, cep telefonlarını ve mobil cihazları içeren bir terim olarak kullanılmaktadır" (Botturi ve Loh, 2008, s. 2). Teknolojinin hızlı gelişimi ve ilerleyişi ile birlikte oyun kavramı özellikle taşınabilir cihazlar sayesinde her an her yerde oynanabilir hale gelmiştir.

Oyun kavramının birey üzerindeki muazzam etkisi ve teknolojinin hızlı yükselişi, insanoğlunun günlük yaşam içerisindeki ihtiyaç ve beklentilerine yönelik özellikle de motivasyona etki bağlamında farklı kavramların arayışına gidilmesine yol açmıştır. Bu arayışlar içerisinde ortaya çıkan kavramlardan en dikkat çekenin “Oyunlaştırma” olduğunu söylemek yanlış olmayacaktır. Deterding, Dixon, Khaled ve Nacke (2011) oyunlaştırma kavramını, "oyun tasarım unsurlarının oyun bağlamı dışındaki durumlarda kullanılması" olarak tanımlamaktadır (s.9). Teknolojinin gelişimine bağlı olarak ortaya çıkan dijitalleşme, motivasyona olumlu etki etmek bağlamında oyunlaştırma ile teknolojinin bir araya gelerek farklı sektörlerde kullanılmasını sağlamıştır. "Günümüzde akıllı telefonların yaygınlaşması ile birlikte pek çok oyunlaştırılmış uygulama da popüler olmuştur. Bunlar arasında en çok kullanıcıya ulaşanlar Foursquare (Swarm), Nike+ ve Mobil Starbuck uygulamalarıdır. Bu noktaya kadar ele alınan oyunlaştırma örneklerini göz önünde bulundurursak neredeyse herkesin bir şekilde oyunlaştırmayı deneyimlediğini ya da aşina olduğunu söylemek mümkündür. Ayrıca bu örneklerin yanı sıra eğitim ve askeriye gibi birçok sistem oyunlaştırılmış sistemlerdir”(Samur ve Özkan, 2019, s. 428).

Günümüz neslinin teknoloji ile ilişkisi düşünüldüğünde, motivasyonu artırıcı etkileri olan oyunlaştırma kavramının teknoloji ile bütünleşmesi sonucunda eğitim-öğretim süreci içerisinde kullanılmasının faydaları olacağı düşünülmektedir. Çağın gerekleri bağlamında yeni nesli eski yöntemlerle derse odaklamanın zor olduğu söylenebilir. Bu doğrultuda da teknolojiyi içerisinde barındıran farklı öğretim tekniklerinin derse entegre edilmesinin gerekliliği açık bir şekilde görülmektedir. Kim, Song, Lockee ve Burton. (2018), pek çok eğitimcinin eğitim sürecinde, öğrencilerin derse olan ilgisi ve katılımı ile ilgili sorunlarla karşılaşmasının yeni bir durum olmadığını, geçmişte eğitimcilerin, motivasyon stratejilerinin kullanımı da dahil olmak üzere çeşitli yöntemler kullanmaya çalıştıklarını belirtmekte ve eğlenceli doğası nedeniyle oyunlaştırmanın derse olan öğrenci katılımını teşvik etmesi ve bu anlamda öğrencinin derse katılım sorunlarını çözmeye yardımcı olması açısından iyi bir çözüm ve öğrenme-öğretme süreci için yararlı olacağını belirtmektedir (s. 29).

Eğitimde yaşanan sorunların temelinde yatan kilit noktanın, günümüz açısından öğrencideki motivasyon eksikliği olduğu söylenebilir. Bu sorun eğitimin her alanında olduğu gibi müzik eğitiminin boyutu olan çalgı eğitiminde de karşımıza çıkmaktadır. "Bu sorunları ortadan kaldırmanın bir yolu da öğrenenlerin motivasyonunu ve adanmışlıklarını artırmak, öğrenme süreç ve araçlarını daha ilgi çekici ve eğlenceli hale getirerek öğrenme deneyimini sürdürülebilir kılmaktır. Bu bağlamda öğrenme ve öğretim süreçlerinin içselleştirilebilmesi, daha anlamlı ve derin öğrenme deneyimlerinin yaşanabilmesi ve öğrenme sürecinin öğrenenin yol aldığı bir yolculuk haline getirilebilmesi için motivasyon, adanmışlık ve sürdürülebilirlik sağlanması, dolayısıyla oyunlaştırılmanın kullanılmasının önemli olduğu söylenebilir" (Sezgin, Bozkurt, Yılmaz ve Linden, 2018, s. 173). Öğrenci çalgısında belli bir seviye gelebilmek adına zor bir sürece girmektedir. Bu süreçte öğrencinin temel, teknik, bilgi ve müzikal becerilerin kazandırılması yolunda etüt, dizi ve egzersiz gibi bir takım çalışmaları yapması gerekmektedir. Ancak bireyin çalgısındaki teknik davranışları geliştirmek adına yapılan bu tarz çalışmaların sürekli tekrarlardan oluşuyor olması ya da genelde bireyde müzikal bir etki yaratmaması, bireyde ilgi ve motivasyon kaybına neden olabilmekte ve bu kayıp başarıya olumsuz yönde etki edebilmektedir. Teknoloji ile oldukça yakın ilişkileri olan bir nesli, teknolojiyi içinde barındıran farklı öğretim yöntemleri ile derse odaklamanın gerekli olduğu düşünülmektedir.

Bu doğrultuda güzel sanatlar liseleri müzik bölümü 9. sınıf çalgı (gitar) eğitimi dersi için oyunlaştırma yöntemine yönelik bir mobil uygulama geliştirilmiştir. İlgili literatür incelendiğinde çalgı eğitiminin içerisinde oyunlaştırma yöntemine yönelik yapılan araştırmaların eksikliği, çalışmayı önemli kılmaktadır.

\subsection{Araştırmanın amacı}

Araştırmada, çalgı (gitar) eğitimi dersi için oyunlaştırma yöntemi doğrultusunda geliştirilen Gitarist adlı mobil uygulamaya yönelik öğrenci görüşlerinin değerlendirilmesi amaçlanmıştır. Bu amaç doğrultusunda geliştirilen mobil uygulamanın genel özellikleri, oyunlaştırma özellikleri, gelişime etkisi, mobil uygulamanın kullanımı kategorilerine ilişkin sorulara cevap aranmıştır.

1. Geliştirilen mobil uygulamanın genel özelliklerine yönelik öğrenci görüşleri nelerdir?

2. Geliştirilen mobil uygulamanın oyunlaştırma özelliklerine yönelik öğrenci görüşleri nelerdir?

3. Geliştirilen mobil uygulamanın gelişime etkisi yönünden öğrenci görüşleri nelerdir?

4. Geliştirilen mobil uygulamanın kullanımına ilişkin öğrenci görüşleri nelerdir? 


\subsection{Araştırmanın önemi}

Bu araştırma; çalgı eğitiminin temel sorunlarından biri olan motivasyon kaybının önlenmesi açısından, geleneksel çalgı eğitimi anlayışına farklı bir bakış açısı kazandırması ve ilgili literatür incelendiğinde alan içerisinde oyunlaştırma yöntemine yönelik çalışmaların mevcut olmaması ve ileride yapılacak çalışmalara yarar sağlaması bakımından önem arz etmektedir.

\section{Yöntem}

\subsection{Araştırma modeli}

$\mathrm{Bu}$ araştırma, nitel araştırma yöntem ve teknikleri doğrultusunda yapılmış betimsel bir çalışmadır. Araştırma yarı yapılandırılmış görüşme tekniği kullanılarak gerçekleştirilmiştir. "Bu görüşme türü, önceden belirlenmiş bir dizi soruların sorulmasını ve özel bazı konulara değinilmesini içermektedir. Bu sorular genellikle her katılımcıya sistematik ve tutarlı bir sırada sorulur, fakat görüşmecilerin bunların dışına çıkma özgürlüğü vardır” (Berg ve Lune, 2015, s. 136).

\section{2. Çalıșma grubu}

Araştırmanın çalışma grubunu, 2019-2020 eğitim-öğretim yılında Kars Gülahmet Aytemiz Güzel Sanatlar Lisesi müzik bölümü 9. Sınıf 6 gitar öğrencisi oluşturmaktadır.

\subsection{Veri toplama araçları}

Araştırmada, çalgı (gitar) eğitimi dersi için oyunlaştırma yöntemi doğrultusunda geliştirilen Gitarist adlı mobil uygulamaya yönelik öğrenci görüşlerinin değerlendirilmesi amacıyla yarı yapılandırılmış görüşme formu, veri toplama aracı olarak kullanılmıştır. Geliştirilen mobil uygulamanın genel özellikleri, oyunlaştırma özellikleri, gelişime etkisi, mobil uygulamanın kullanımı kategorilerine ilişkin hazırlanan görüşme formunda 1 kapalı uçlu, 7 açık uçlu olmak üzere toplam 8 soru bulunmaktadır

Çalışmanın inandırıcılığını (iç geçerlik) sağlamaya yönelik nitel araştırma ve konu alan uzmanının, araştırmayı çeşitli boyutlarıyla incelemesi sağlanarak uzman incelemesi yoluna gidilmiştir. Bu aşamalarda elde edilen veriler, uzmanlara sunulmuş ve verilerin geçerliği uzmanlar ile birlikte değerlendirilmiştir. Çalışmada elde edilen veriler bulgular bölümüne aktarılırken, temalar ve kodlar dışında katılımcılardan doğrudan ifadelere yer verilmiş ve ayrıntılı betimleme yoluyla aktarılabilirliğin (dış geçerlik) arttırılması sağlanmıştır.

Nitel araştırmalarda olgu ve olayların, ortama ve zamana bağlı olarak gösterdiği değişkenlik nedeniyle tekrar edilebilirliklerinin mümkün olmadığı varsayımından kaynaklı, güvenirlik kavramı yerine tutarlık kavramı kullanılmakta ve bu anlamda nitel araştırmalarda tutarlık incelemesi (iç güvenirlik) yapılması önerilmektedir (Yıldırım ve Şimşek, 2008, s. 271). Çalışmada, veri toplama araçlarının geliştirilmesinde, verilerin toplanmasında ve elde edilen verilerin analiz kısmı süreçlerinde, bir meslektaş ve konu alan uzmanı tarafindan tutarlık incelemesi yapılmıştır. "Bu stratejinin amacı araştırmaya dışarıdan bir gözle bakılması ve araştırmacının baştan sona gerçekleştirdiği araştırma etkinliklerinde tutarlı davranıp davranmadığını ortaya koymaktır” (Yıldırım ve Şimşek, 2008, s. 272). Çalışmanın teyit edilebilirliğini (dış güvenirlik) sağlamak amacıyla çalışmanın temel aşamalarına yönelik açıklayıcı bilgilere yer verilmiş ve çalışmadan elde edilen ham veriler ileride başka bir araştırmada karşılaştırma yapmak üzere arşivlenmiştir.

\subsection{Verilerin toplanması}

Araştırmada, Gitarist adıyla geliştirilen mobil uygulamanın, Kars Gülahmet Aytemiz Güzel Sanatlar Lisesi müzik bölümü 9. Sınıf gitar öğrencilerine 8 hafta süren uygulaması yapılmış ve uygulama sonucunda bire bir görüşmeler neticesinde, öğrencilerin mobil uygulamaya yönelik görüşleri yarı-yapılandırılmış görüşme formu kullanılarak belirlenmiştir. Öğrenciler ile yapılan bire bir görüşmelerde ses kaydı alınmış ve sonrasında bu kayıtlar hazırlanan görüşme formlarına aktarılmıştır.

\subsection{Verilerin çözümlenmesi}

Araştırmada nitel veri toplama araçlarından yarı yapılandırılmış görüşme formu kullanıldığından, görüşme değerlendirmelerinden elde edilen verilerin çözümlenmesi için nitel veri analizi yöntemlerinden içerik analizi kullanılmıştır. "İçerik analizinde temel amaç, toplanan verileri açıklayabilecek kavramlara ve ilişkilere ulaşmaktır. Betimsel analizde özetlenen ve yorumlanan veriler, içerik analizinde daha derin bir işleme tabi tutulur ve betimsel bir yaklaşımla fark edilemeyen kavram ve temalar bu analiz sonucu keşfedilebilir. Bu amaçla toplanan verilerin önce kavramsallaştırılması, daha sonrada ortaya çıkan kavramlara göre mantıklı bir biçimde düzenlenmesi ve buna göre veriyi açıklayan temaların saptanması gerekmektedir” (Yıldırım ve Şimşek, 2008, s. 227).

Öncelikli olarak görüşme formlarından elde edilen veriler birkaç kez okunmuş ve sonrasında MAXQDA 2020 programı üzerinde bu verilerin kodlaması yapılmış ve temalar oluşturularak verilerin içerik analizleri yapılmıştır. 


\section{Bulgular}

\subsection{Geliştirilen mobil uygulamanın genel özelliklerine yönelik bulgular}

Öğrencilerden ilk olarak uygulamayı değerlendirmeleri istenmiştir. Verdikleri cevaplar doğrultusunda üç kod ortaya çıkmıştır. Böylece öğrencilere göre mobil uygulama; zor, çalışmaya yönelten ve eğlenceli özelliklere sahiptir. Örnek görüşler şu şekildedir.

Ö5: Çalışmaya teşvik ediyor. Yapamayınca hırs oluyor ve daha çok çalışıyorsun.

Ö3: Başlangıç seviyesi için biraz beni zorladı.

Ö4: Oynaması çok zevkli bence.

Aşağıdaki tablo öğrencilerin yazılım için en yoğun hangi ifadeyi kullandığını göstermektedir.

Tablo 1

Öğrencilerin mobil uygulamanın özellikleri hakkındaki görüşlerinin dağılımı

\begin{tabular}{lcc}
\hline & Frekans & Yüzde \\
\hline Eğlenceli & 5 & 83.33 \\
Çalışmaya yönelten & 4 & 66.67 \\
Zor & 3 & 50.00 \\
Kodlanmıș BELGELER & 6 & 100.00 \\
Kodlanmamış BELGELER & 0 & 0.00 \\
ANALIZ EDILEN BELGELER & 6 & 100.00 \\
\hline
\end{tabular}

Tablo1'e göre öğrenciler mobil uygulamanın eğlenceli olması ile ilgili 5 ifade kullanmış, çalışmaya yöneltmesi ile ilgili 4, zor olması ile ilgili de 3 ifadede bulunmuşlardır. Uygulamanın bazı alıştırmaları için zor diyen öğrenciler, bu görüşlerinden yapamadıkları alıştırmaları tekrar tekrar deneyince vazgeçtiklerini söylemişlerdir. Bu anlamda uygulamanın önyargıları ya da başarısızlığı yıkmak için önemli bir çıktısı olduğu söylenebilir.

\subsection{Geliştirilen mobil uygulamanın oyunlaştırma özelliklerine yönelik bulgular}

Öğrencilere uygulama içerisinde yer alan oyun elementleri ile ilgili sorular sorulmuştur. Öğrenciler yoğunlukla seviye ve ödül üzerine görüşler bildirirken, bir öğrenci puan sistemi hakkındaki görüşünü belirtmiştir. Bu doğrultuda verilen ifadeler, uygulamanın oyunlaştırma özellikleri olarak değerlendirilecektir. Seviyeler ve ödüller olarak iki alt kod öğrencilerin görüşlerini nitelemiştir. Buna göre, öğrencilerin seviyeler ile ilgili görüşleri şu şekildedir:

Ö1: Bence seviyelerde sıralanış çok güzel hocam. Basitten zora doğru giden ve alıştırmaları çok olan bir uygulama

Ö2: Uygulamanın seviye seviye yavaş bir şekilde ilerletmesi çok güzeldi.

Ö5: Kolay başladı. Sonrasında zorlaşmaya başladı. Ama genel anlamda çok fazla zorlanmadım.

Ö6: Illk basitti. Sonra ortalarda biraz zorlandım. ...ilk anda geçemesem bile başa dönüp sürekli oynadıkça başardım.

İfadelerden, öğrencilerin seviyelerle öğrenmeyi benimsedikleri, seviyelerin basitten zora doğru ilerlediği ve zorlandıkları kısımları tekrar tekrar deneyerek oynadıklarında başarıyı yakaladıkları anlaşılmaktadır. Ödüller ile ilgili görüşleri ise şu şekildedir:

Tablo 2

Öğrencilerin ödüller hakkındaki görüşleri

\begin{tabular}{cl}
\hline Öğrenci & \multicolumn{1}{c}{ Görüş } \\
\hline Ö1 & $\begin{array}{l}\text { Koleksiyona eklenen gitarlar sayesinde bilmediğim gitarları öğrenmiş oldum. } \\
\text { Gitaristlerin sonlarda çıkıp bizi tebrik etmesi daha çok hoşumuza gidiyor ve daha çok oynamak istediğim oldu. Övgü almak } \\
\text { Öok hoşuma gitti. }\end{array}$ \\
Ö3 & $\begin{array}{l}\text { Bölüm sonlarında farklı gitaristler çıkıyordu. Güzel şeyler söylüyorlardı. Bence motive edici olabiliyor. Ödüller zaten gitarla } \\
\text { alakal. Bence güzel }\end{array}$ \\
Ö4 & $\begin{array}{l}\text { Seviyelerin sonunda gitaristleri görmek ve onlardan güzel sözler duymak beni çok etkiledi. Gitar ödülü de önemli. .....Bunun } \\
\text { dişında bonus ödülünü merak ettim acaba ne var diye o yüzden sanırım herkesten önce bitirdim. }\end{array}$ \\
Ö5 & $\begin{array}{l}\text { Bence güzel olmuş. Rekabet ortamı oluşturmuş. Birinci olmak için daha çok çalışıorsun. Her seviye sonunda bir gitaristin } \\
\text { çııp bize bir şeyler söylemesi çok güzel ve faydalı oluyor bence. }\end{array}$ \\
Ö6 & $\begin{array}{l}\text {...daha fazla oynamama neden oldu ödüller. Seviyelerin sonunda çıan gitarcılar çok etkiledi beni. Çok hoşuma gitti. Gitar } \\
\text { ödülü de çok iyiydi. }\end{array}$
\end{tabular}

Tablo 2'ye göre öğrenciler ödüllerden çok keyif almıştır. Ödüller, motivasyonlarını artırmış, yarattığ1 rekabet ortamı nedeni ile daha fazla oynamalarını dolayısıyla daha fazla çalışmalarını sağlamıştır. Seviyelerin sonunda 
çıkan gitaristlerden etkilendiklerini belirtmeleri ise mobil uygulamanın gitar çalmayı öğretmekten daha fazlasına sahip olduğunu göstermektedir. Puan ile ilgili görüş ise şu şekildedir:

Ö1: Oyun oynarken doğru çaldı̆̆ımda puanların artışını görmek ve notaların yeşil renk olması hem heyecan yaratyordu hem de daha motive ediyordu.

\subsection{Geliştirilen mobil uygulamanın gelişime etkisine yönelik bulgular}

Öğrencilerin ifadelerinden, uygulama sayesinde gelişim gösterdikleri alanlar olduğu tespit edilmiştir. Buna göre ögrenciler, çalgılarında ilerleme konusunda ve kişisel gelişimlerinde geliştiklerini ifade etmişlerdir. Bununla birlikte, gelişime etki bakımından değerlendirilebileceğimiz bir olumsuz görüş mevcuttur.

Öğrencilerin çalgılarında gösterdikleri gelişimi ifade eden görüşler, mobil uygulamanın her bir başarı çıktısını temsil etmektedir. Bu anlamda aşağıdaki şekilde her bir öğrencinin konu ile ilgili görüşü sunulmaktadır.

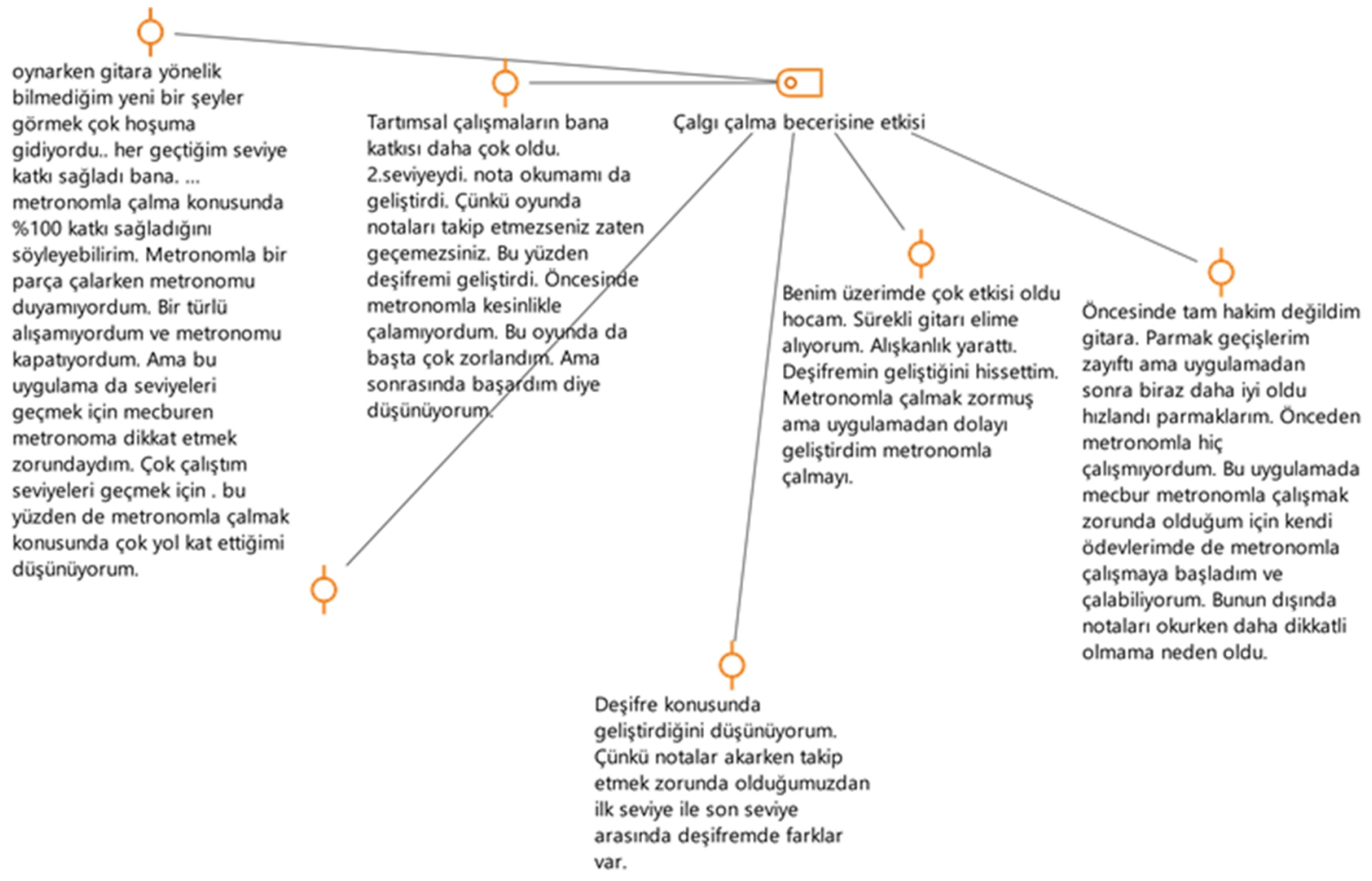

Şekil 1. Öğrencilerin çalgı çalma becerilerine ilişkin gelişim ifadeleri

Şekle göre, öğrenciler bu konuda yoğun ve olumlu ifadelerde bulunmuşlardır. Öğrenciler genel olarak mobil uygulamanın, çalışmaya teşvik etmesi, metronomla çalışma konusunda başarı sağlaması, deşifrelerine olumlu etki etmesi gibi gelişimlerine katkı sağlayan ifadelerde bulunmuşlardır. Öğrenciler gelişim ile ilgili ifadelerde bulunurken, kişisel olarak geliştiklerini gösteren ifadelere yer vermişlerdir. Uygulamanın, her seviyeden sonra Türkiye'nin önde gelen gitaristlerinden öğrencilere tebrik ve motivasyon konuşması imkanı sağlaması ve bunun yanı sıra uygulamada üstün başarı gösterdiklerinde dönemsel gitarların açılarak koleksiyona eklenmesi, öğrencileri çok etkilemiştir. Bu etki ifadelerine de yansımıştır.

Ö4: Celil Refik Kaya tanımıyordum sonradan araştırdım.

Ö5: Gitar ödülleri bilgilendirici. Bazı şeyleri ögrenmiş oldum. Çalışma saatlerim arttı hocam. Çalışma şeklim değişti.

Ö6: Seviyelerin sonunda çıkan gitarcılar çok etkiledi beni. Çok hoşuma gitti. Gitar ödülü de çok iyiydi. Eskiden böyle gitarlar olduğunu bilmiyordum.

Mobil uygulama, genel kültür bakımından da öğrencilere katkıda bulunmuş, onları araştırmaya, çalışmaya ve öğrenmeye teşvik etmiştir. Bununla birlikte, iki öğrenci uygulamadan olumsuz etkilendiği ile ilgili görüş bildirmiştir.

Ö3: Motivasyonumu belli zamanlarda biraz kötü etkiledi hocam. Bazı alıştırmalarda çok uğraştım. Acaba bendemi bir sıkıntı var diye düşünmeye başladığım zamanlar da oldu. O alıştırmalarda biraz motivasyonum düştü. Ama sadece yapamadığımı düşündüğ̈̈m alıştırmalarda sıkıntım vardı. 
ö6: İlk kurduğunuzda çok fazla oynamadım. Birkaç kez oynadıktan sonra ĕ̆lenceli gelmeye başladı. Hatta evde uygulamayı oynamaktan diğer dersleri biraz boşlamaya başladım.

Öğrencilerden biri, geçemediği seviyelerden dolayı motivasyonunun düştüğünü, bir diğeri ise uygulamanın eğlencesine kapılıp diğer derslerine çalışmadığını belirtmiştir. Bu sıkıntıların, teknolojik öğrenmenin bir kültür olarak yerleşmesi durumunda aşılacağı düşünülmektedir.

\subsection{Geliştirilen mobil uygulamanın kullanımına yönelik bulgular}

Öğrencilere mobil uygulamanın kullanımı ile ilgili çeşitli sorular sorulmuştur. Bu bakımdan uygulamanın kullanımı ile ilgili kategoriler, mobil uygulamanın derste kullanımı, diğer derslerde bu tarz uygulamaların kullanımı ve benzer diğer uygulamaların kullanımıdır.

Öğrenciler mobil uygulamanın derslerinde kullanılması ile ilgili görüşlerde bulunmuşlardır. Bu görüşlere örnek olarak aşağıdakiler gösterilebilir.

Ö1: Dersler genelde klasik işleniyor hocam. Bu yüzden de derse gittiğimizde ne yapılacağın biliyoruz genelde ve bu da biraz sıradanlıktan dolayı derse olan ilgimizi düsürüyor gibi. Ama bu uygulama ile siz de görüyordunuz hocam derste uygulamayl yaparken heyecanlaniyorum. Bu tarz teknolojik uygulamalar bence daha iyi derste. Çünkü aynı zamanda eğleniyorum ve derse hep isteyerek geldim. Sürekli aynı şeyleri yapmak bazen sikıcı oluyor. Ama uygulamayı oynarken devamında nelerin geleceğini bilmediğin için merakla bekliyorsun.

Ö5: Eğlenceli olmasindan dolayı derse başka bir hava kattı.

ö6: Ders daha eğlenceli hale geldi bence. Sikıcı olduğu zamanlar çok oluyordu. Şimdi daha istekli oluyorum bu derse karşı. Bu derste kullanılması çok güzel oldu bence.

İfadelerden görüldüğ̈̈ gibi, öğrenciler derste uygulamanın kullanılması ile birlikte daha fazla keyif aldıklarını belirtmişlerdir. Bu anlamda diğer derslerinde de bu tarz uygulamalar kullanmak isteyeceklerdir. Aşağıdaki şekil diğer derslerde de bu tarz uygulamaları kullanmak isteyen öğrencileri göstermektedir.

\begin{tabular}{|c|c|c|c|c|c|c|c|}
\hline \multicolumn{2}{|c|}{ Kod Sistemi } & ö1 & ö2 & ö3 & ö4 & ö5 & ö6 \\
\hline$\checkmark$ & $\odot$ Uygulama & & & & & & \\
\hline & $\checkmark$ Yazılımın kullanımı & & & & & & \\
\hline & $\checkmark$ ¿ Diğer derslerde kullanımı & & & & & & \\
\hline & $e_{\text {Kullanılsın }}$ & " & " & " & " & घ & घ \\
\hline
\end{tabular}

Şekil 2. Başka derslerde bu tarz uygulama kullanmak isteyen öğrencilerin dağılımı

Şekilden de görüldüğü üzere, tüm öğrenciler bu tarz uygulamaların diğer derslerde kullanılmasını isteyen ifadelerde bulunmuştur. Kullanılmamasını isteyen öğrencinin olmaması, uygulamanın kullanıcısı öğrenciler tarafından sevildiğini göstermektedir. Konu ile ilgili şöyle görüşlerde bulunmuşlardır:

Ö2: Cok iyi olur hocam. Ben piyano uygulaması kullandım biraz ve o kadar az kullanmama rağmen diğer arkadaşlarımdan daha hızlı ilerledim. Bence diğer enstrümanlar içinde olsa çok güzel olur diye düşünüyorum.

Ö4: Iyi olabilir. Sadece tahtadan ders işlemek yerine dersi eğlenceli hale getirir diye düșünüyorum. Bazen çok sikıcı olabiliyor dersler.

ö5: Derse teşvik ediyor hocam. Bu yüzden diğer derslerde de kullanılması bence çok güzel olur

Ö6: Gitar dersinde çok eğlendim bu uygulamayla. Bence diğer dersleri de böyle uygulamalar eğlenceli hale getirebilir ve bence olmast gerekli.

Öğrenciler, eğlendikleri ve çalışma konusunda teşvik oldukları için diğer derslerde de bu tarz uygulamalar kullanmayı istemiş̧lerdir. Yukarıdaki ifadelerden birinde öğrenci, piyano uygulaması kullandığını ve bu sayede diğer öğrencilerden daha hızlı ilerlediğini belirtmiştir. Bu anlamda öğrencilerin daha önce bu tür uygulamalar kullanıp kullanmadıkları sorulup deneyimlerini paylaşmaları istenmiştir. Aşağıdaki şekil öğrencilerin daha önce bu tarz mobil uygulamalar kullanıp kullanmadığı ile ilgili verdiği cevapları göstermektedir. 


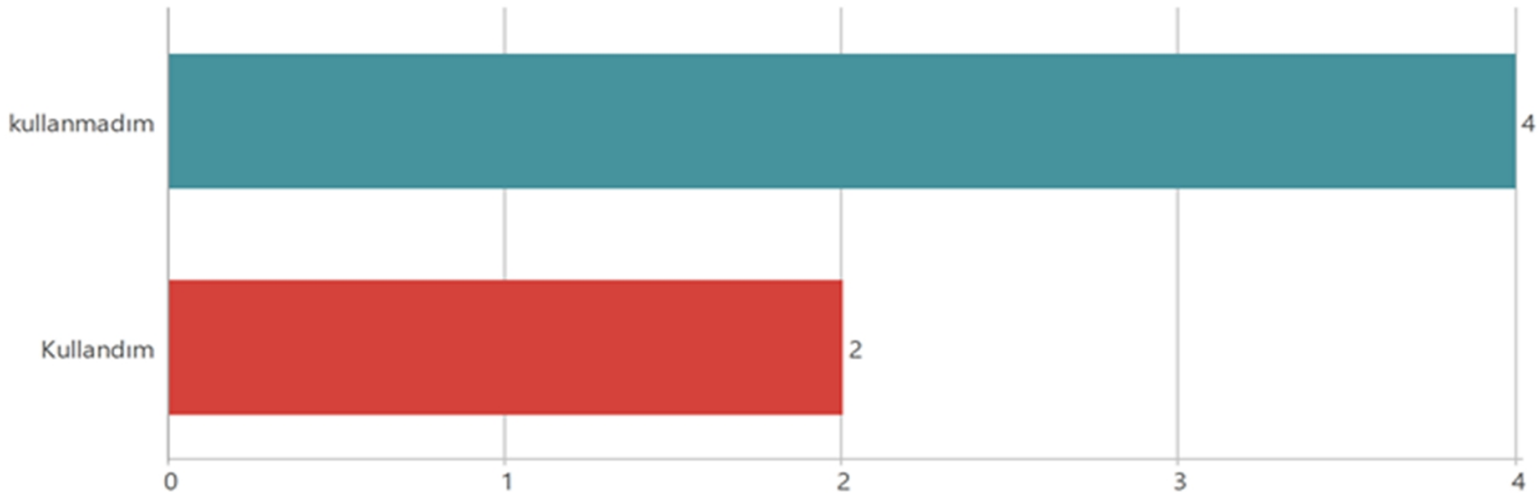

Şekil 3. Öğrencilerin daha önce bu tarz mobil uygulama kullanma durumları

Şekilden de görüldüğü üzere, daha önce uygulama kullanan öğrenci sayısı 2 iken, kullanmayanlar 4 kişidir. Kullanmayanlar neden kullanmadıkları ile ilgili görüş bildirmemişlerdir. Ancak kullananlardan birinin ifadesi ilgi çekicidir.

Ö2: Piyano için bir kere denedim. Ama genelde ücretli olduklarl için uygulamalar bir yere kadar oynayabiliyorsunuz. O yüzden piyano uygulamasına da çok bakamadım.

Öğrenci, piyano uygulamasını denemiş ancak ücretli olmasından dolayı sürekli kullanımı mümkün olmamıştır. Bu bağlamda "Gitarist" adlı mobil uygulamasının, eğitime katkı anlamında daha ulaşılabilir ve faydalı olacağını göstermektedir.

\section{Tartışma, sonuç ve öneriler}

$\mathrm{Bu}$ araştırmada, çalgı (gitar) eğitimi dersi için oyunlaştırma yöntemi doğrultusunda geliştirilen Gitarist adlı mobil uygulamaya yönelik öğrenci görüşlerinin değerlendirilmesi amaçlanmış ve bu amaç doğrultusunda geliştirilen mobil uygulamanın genel özellikleri, oyunlaştırma özellikleri, gelişime etkisi, mobil uygulamanın kullanımı kategorilerine ilişkin konuya yönelik mevcut durum değerlendirilmesi yapılmıştır.

Öğrenciler 8 haftalık süreçte uygulamayı kullanıp, deneyimlerini paylaşmışlardır. Öğrenciler mobil uygulamanın, çalışmaya yöneltici ve eğlenceli olduğunu belirtmişlerdir. Seviyelerin kolaydan zora kurgulanmasını iyi olarak nitelemişler, seviye sonundaki ödüllerden ise çok etkilendiklerini, motive olduklarını bildirmişlerdir. Bu anlamda öğrenciler, uygulamanın çalgı çalma becerilerini geliştirme etkisinin yanında, uygulamada yer alan gitarları ve gitaristleri yeni öğrendikleri için kişisel olarak da geliştiklerini bildirmişlerdir. Oyunlaştırma özelliklerinin, derste birbirleri arasında rekabet hissi yarattığını ancak bu durumun tekrar etmeyi ve öğrenmeyi tetiklediğini bildirmişlerdir. Uygulama sayesinde metronomla çalışmaya alıştıklarını, parmak geçişlerinin hızlandığını ve deşifrelerinin geliştiğini de bildirmişlerdir. Erim ve Yöndem (2009) deney ve kontrol gruplu yaptıkları çalışmada, video model destekli öğretimin, başlangıç aşamasındaki klasik gitar öğrenci performanslarına olan etkisini araştırmışlar ve çalışmanın sonucunda bu öğretim şeklinin, öğrencilerin gitar tutuş, sağ ve sol el ve eser üzerindeki performanslarına olumlu yönde etki ettiği sonuçlarına ulaşmışlardır. Teknolojik yöntemlerin öğrenci üzerindeki etkisi anlamında çalışmanın, Erim ve Yöndem'in çalışmasıyla benzer sonuçlara ulaştığını söylemek mümkündür. Öğrenciler Gitarist adlı uygulamayı derste kullanmayı benimsemişler, diğer derslerde de bu tarz uygulamaların kullanılmasını istemişlerdir. Uygulama sayesinde, çalışma isteklerinin, derse ilgilerinin ve motivasyonlarının arttığını bildirmişlerdir. Wagner (2016) çalışmasında, oyunlaştırmanın öğrencilerin motivasyonu üzerindeki etkisini görmek adına küçük dijital oyunlara kendi piyano egzersizlerini eklemiştir. Araştırmacı çalışmasında akış deneyimine odaklanmış ve bu doğrultuda katılımcılara akış deneyimlerine yönelik görüşme soruları yöneltmiş̧ir. Araştırma sonucunda araştırmacı, müzik eğitiminde öğrencileri motive etmede akış deneyiminin faydalarının olduğu bunun yanı sıra teknolojinin öğrencinin ve öğretmenin ders saatleri dışında bağlantı kurmasına ve bireysel uygulamalarında öğrencilere geri bildirim sağlamasına yardımcı olduğu sonuçlarına ulaşmıştır.

Günümüz neslinin ihtiyaçları ve beklentileri göz önünde bulundurulduğunda, eğitim sistemi içerisinde teknolojiyi barındıran farklı yöntemlerin gerekliliği kaçınılmaz hale gelmiştir. $\mathrm{Bu}$ anlamda çağın getirdiklerini takip edebilmenin ve eğitim-öğretim sürecine dahil edebilmenin oldukça önemli olduğu düşünülmektedir. Araştırmanın alt problemlerinin çıktıları doğrultusunda aşağıdaki önerilerde bulunulabilir.

$\checkmark$ Teknolojik gelişmelerle birlikte görünür hale gelen oyunlaştırmanın etkileri göz önünde bulundurulduğunda, çalışma kolaylığı sağlaması ve öğrenciyi çalışmaya teşvik etmesi açısından bu tarz uygulamalardan faydalanılabileceği önerilmektedir. 
$\checkmark \quad$ Sonuçlardan anlaşıldığı üzere, oyunlaştırmanın öğrenciler üzerinde motivasyonu artırıcı etkileri olduğu görülmektedir. Bu noktadan hareketle müzik eğitiminin diğer alanlarında da oyunlaştırma yönteminden faydalanılabileceği önerilmektedir.

$\checkmark$ Öğrencinin oyunlaştırma teknikleri kapsamında kendi kendini kontrol ederek doğru çalışabilmesi ve çalışma disiplinini geliştirmesi açısından ders dışı çalışmalarda, bu tarz uygulamalardan faydalanılabileceği önerilmektedir.

$\checkmark \quad$ Klasik gitar tarihi, literatürü, bestecileri gibi daha kuramsal bilgilerin yoğunlukta olduğu çalışma alanlarında etkin ve etkili biçimde oyunlaştırma yönteminden faydalanılabileceği önerilmektedir.

$\checkmark$ Günümüz neslinin teknoloji ile olan ilişkisi neticesinde gelişen beklentilerini, eğitim-öğretim süreci içerisinde geleneksel yöntemlerle karşılamanın zorlaştığı görülmektedir. Sonuçlarda da görüldüğü üzere pilot uygulama aşamasında öğrenciler, çalgı eğitimi dışında diğer derslerde de bu tarz uygulamaların kullanılmasına yönelik düşüncelerini belirtmişlerdir. Bu bağlamda geleneksel yöntemlere alternatif olarak diğer derslere yönelik bu tarz çalışmaların yapılması önerilmektedir.

$\checkmark$ Geliştirilen uygulama, bireysel çalgı eğitimi dersi kapsamında, gitar dışında diğer çalgılara da uyarlanabilir bir özelliğe sahiptir. Bu doğrultuda Gitarist adlı uygulamanın, diğer çalgılara uyarlanması önerilmektedir.

\section{Kaynakça}

Berg, B. L., \& Lune, H. (2015). Sosyal bilimlerde nitel araştırma yöntemleri. (H. Aydın, Çev.) Konya: Eğitim Yayınevi.

Botturi, L. ve Loh, S. C. (2008).Games in education. Miller, C. T. (Ed.), In Games: Purpose and Potential in Education (1-20). Newyork, NY, USA:Springer Science+Business Media, LLC.

Deterding, S., Dixon, D., Khaled, R., \& Nacke, L. (2011). From game design elements to gamefulness: Defining gamification. In Proceedings of the 15th International Academic MindTrek Conference: Envisioning Future Media Environments (s. 9-15). Finlandiya: ACM.

Erim, A., \& Yöndem, S. (2009). Video model destekli öğretimin gitar performansına etkisi. Dokuz Eylül Üniversitesi Buca Ĕ̆itim Fakültesi Dergisi, 26, 45-55. Erişim adresi: https://dergipark.org.tr/tr/download/ article-file/235047

Huizinga, J. (2006). Homo Ludens oyunun toplumsal işlevi üzerine bir deneme (M. A. Kılıçbay, Çev.). İstanbul: Ayrıntı Yayınları.

Kim, S., Song, K., Lockee, B. ve Burton J. (2018). Gamification in learning and education: Enjoy learning like gaming. Switzerland: Springer International Publishing AG.

Samur, Y., \& Özkan, Z. (2019). Oyun, oyun elementleri, oyun temelli öğrenme, eğitsel oyun tasarımı, dijital oyunlar, oyunlaştırma ve uygulamaları. Y. K. Türel (Ed.), Öğretim teknolojileri (s. 413-440) içinde. Elazığ: Asos Yayinevi.

Sezgin, S., Bozkurt, A., Yılmaz, E. A.ve Linden, N. (2018). Oyunlaştırma, eğitim ve kuramsal yaklaşımlar: öğrenme süreçlerinde motivasyon, adanmışlık ve sürdürülebilirlik. Mehmet Akif Ersoy Üniversitesi Eğitim Fakültesi Dergisi, 45, 169-189. doi: https://doi.org/10.21764/maeuefd.339909

Wagner, C. (2016). Digital gamification in private music education. Antistasis, 7(1), 115-122. Erişim adresi: https://pdfs.semanticscholar.org/51fb/3dde485895774bc3e96a709b5066e96af747.pdf

Yıldırım, A., \& Şimşek, H. (2008). Sosyal bilimlerde nitel araştırma yöntemleri. Ankara: Seçkin Yayıncılık. 